Earth Syst. Dynam. Discuss., doi:10.5194/esd-2016-57, 2016

Manuscript under review for journal Earth Syst. Dynam.

Published: 16 November 2016

(c) Author(s) 2016. CC-BY 3.0 License.

\title{
Multi-method assessment of reservoir effects on hydrological droughts in an arid region
}

Sally Rangecroft ${ }^{1}$, Anne F. Van Loon ${ }^{1}$, Héctor Maureira ${ }^{2}$, Koen Verbist ${ }^{3,4}$, David M. Hannah ${ }^{1}$

${ }^{1}$ School of Geography, Earth and Environmental Sciences, University of Birmingham, Edgbaston, Birmingham B15 2TT, UK

${ }^{2}$ CAZALAC, Water Center for Arid and Semiarid Zones in Latin America and the Caribbean, Benavente \#980, La Serena, IV Región, Chile

${ }^{3}$ UNESCO, Enrique del Piano 2058, Santiago, Providenica, Chile

${ }^{4}$ UNESCO Chair for Eremology, Department of Soil Management, Ghent University, Coupure Links 653, 9000 Gent, Belgium

Sally Rangecroft: s.rangecroft@bham.ac.uk 
Earth Syst. Dynam. Discuss., doi:10.5194/esd-2016-57, 2016

Manuscript under review for journal Earth Syst. Dynam.

Published: 16 November 2016

(c) Author(s) 2016. CC-BY 3.0 License.

\begin{abstract}
Increasing pressures on water resources in arid regions have led to their increased management and construction of dams; however, the impacts of these anthropogenic activities on hydrological droughts have yet to be incorporated and assessed. Here, the impact of the Santa Juana dam on hydrological drought characteristics downstream has been analysed in the Huasco basin in northern Chile. Two different methods of drought analysis, threshold level method and standardised indices, were applied to observed and modelled data. An upstream-downstream approach was taken for the observation data, analysing the "disturbed" (post-dam) period and the "undisturbed" (pre-dam) period to allow for an assessment of the onset of the significant anthropogenic activity on the hydrological regime. Modelled data from the Water Evaluation And Planning (WEAP) model generated a naturalised scenario and human-influenced scenario for similar analysis. Our findings show the characteristics of recent drought events in the basin $(1965-2013)$. The reservoir is shown to help alleviate hydrological droughts by reducing frequency, duration and intensity of drought events, though it did not alleviate major multi-year drought events. A delay in timing of drought events has been observed also with the presence of the dam. The reliability of these different methods and approaches to quantify the impact of the dam are evaluated, with concluding recommendations that the threshold level method using an undisturbed threshold may be the most suitable. These findings show an applicable way forward with quantifying the human influence on hydrological droughts, a method that can be applied elsewhere, and on other human activities.
\end{abstract}

\title{
1. Introduction
}

Drought is an important natural hazard that can lead to severe environmental and socio-economic impacts in many regions of the world with losses in agriculture, damages to natural ecosystems and social disruption (Prudhomme et al., 2014; Vicente-Serrano et al., 2014). Drought is regarded as a deficit in available water compared to the normal conditions ('normal' based on an average over a certain period or a defined level), which can be established for a range of variables, such as deficit in precipitation, soil moisture, streamflow, or groundwater. Classically, most drought definitions consider drought as a natural phenomenon, with climate variability as the only driver of drought. However, recently there has been a call to acknowledge and include the anthropogenic influence on drought, drought processes and propagation (AghaKouchak et al., 2015; Wanders \& Wada, 2015; Van Loon et al., 2016a; Van Loon et al., 2016b). Anthropogenic activities can cause, exacerbate or alleviate drought situations (Vogel \& Drummond, 1993; Van Loon et al., 2016a) through directly and indirectly affecting natural drought propagation and processes (see figure 1, Van Loon et al., 2016a). For example, human activities can affect the amount of land surface runoff and infiltration (e.g. land use practices, urbanization, deforestation), water availability (e.g. water abstraction, agriculture/ irrigation) and water storage (e.g. reservoirs). In recent years research has started to incorporate and investigate the anthropogenic impact on drought (e.g. Wada et al., 2013; Van Loon \& Van Lanen, 2013; Mehran et al., 2015; Wanders \& Wada, 2015; Liu et al., 2016; Van Loon et al., 2016a; Van Loon et al., 2016b).

Globally, Wander and Wada (2015) found that drought duration, deficit and intensity were all worsened by human activity (e.g. water abstractions) through a comparison of the scenarios for the pristine and human-influenced situation. A limited number of publications have quantified the human impact on hydrological droughts in case studies through a comparison of the naturalised situation with the actual. In a few European basins, the abstraction of groundwater on the 
Earth Syst. Dynam. Discuss., doi:10.5194/esd-2016-57, 2016

Manuscript under review for journal Earth Syst. Dynam.

Published: 16 November 2016

(c) Author(s) 2016. CC-BY 3.0 License.

hydrological system has been found to result in worse drought impacts than naturally expected or than meteorological drought impacts (Van Loon \& Van Lanen, 2013; 2015). Similarly in China, hydrological droughts durations and deficits were amplified with the presence of human disturbances (Liu et al., 2016).

These studies have demonstrated that in general, human water use and activities increases drought duration and severity; however, this effect can be (partly) compensated by reservoir regulations that release stored water during the dry period (Wanders \& Wada, 2015). Therefore, it is important to note that human activities (such as reservoirs) can positively affect the hydrological system through an increased storage capacity, helping with alleviation and resilience during drought conditions (Mehran et al., 2015; AghaKouchak et al., 2016), reducing the impact of drought through a change in the timing of water availability, increasing availability during the dry season (Wanders \& Wada, 2015). Flow regulations due to dams and reservoir management are known to be the largest cause of hydrological alteration (Petts \& Gurnell, 2005). However, detailed research on the impact of dams to downstream drought characteristics such as frequency, timing, duration and intensity are limited. It is important to fully understand the impact of this human activity and management on the hydrological system to improve our resilience and adaptation/response to drought.

In arid and semi-arid regions where water availability is mainly supplied by upstream mountainous areas (e.g. stored as snow and glaciers) or from precipitation in limited periods of the year, reservoirs are extremely important for water resource management, especially during periods of meteorological drought. Drought can have large negative consequences in arid and semi-arid regions and countries due to the high demand for the available resources and the low resilience in these regions. Although Chile is climatically very diverse, it is a country that suffers from multi-year droughts. An increase in frequency and severity of drought with a changing climate is projected for Chile and across the rest of South America (Magrin et al., 2014; WRI Aqueduct, 2014) with negative impacts associated. In this study we focus on the north of Chile where agriculture is an important livelihood, despite the extremely arid climate. With increases in demand from population changes and associated food and water security, and changes in supply through temperature increases and alterations of precipitation patterns, there are increasing pressures on finite water resources and their management (Meza, 2013; Rangecroft et al., 2013).

Therefore, there is a need to improve our knowledge on how human activities are impacting on drought to enable better drought preparation and mitigation, especially in these vulnerable, arid regions. It is currently unclear on what is the best method for assessing and quantifying the impact of human activities on hydrological droughts. Subsequently, to address these research gaps the aim of this paper is to assess the impacts of anthropogenic activity (i.e. dam impoundment and reservoir storage) on hydrological drought using long-term observations (1965-2013) and model simulations. This is done using the case study of the Santa Juana dam (built by 1998) in the Huasco basin, Northern Chile, analysing the impact of this recent human activity on drought occurrence and characteristics downstream. Through this case study, we test the utility of two different methods of analysis (standardised indices and threshold level) to find the most appropriate method for identifying and quantifying the human 'component' of hydrological drought.

\section{Study area}

\subsection{Huasco Basin}

The Huasco River catchment lies at the limit of the extremely arid Atacama Desert in the north of Chile $\left(28-29^{\circ} \mathrm{S}\right)$ (Figure 1). The Huasco catchment covers $9,850 \mathrm{~km}^{2}$ and the altitude in the basin 
Earth Syst. Dynam. Discuss., doi:10.5194/esd-2016-57, 2016

Manuscript under review for journal Earth Syst. Dynam.

Published: 16 November 2016

(c) Author(s) 2016. CC-BY 3.0 License.

ranges from sea level to 5,200 $\mathrm{m}$ above sea level (asl). Here, we focus on the upper-mid section of basin were the dam is located $\left(28^{\circ} \mathrm{S}, 70^{\circ} \mathrm{W}\right.$ ) (indicated with a blue triangle on Figure 1 ). The Huasco Valley hosts a population of 255,000 inhabitants (Basin-info, 2014), and as in many other semi-arid regions in the world, the population of the valley relies on the water resources from the upper catchments in high altitude areas (Viviroli et al., 2007). Although there is limited glacier extent, glacial meltwaters combined with snowmelt are an important component of the hydrological resources (Favier et al., 2009). Annual glacial melt can contribute up to $23 \%$ of streamflow in the basin, providing vital water for the regional economy (Nicholson et al., 2009; Gascoin et al., 2011), with agriculture acting as the main water consumer ( $85 \%$ of total).

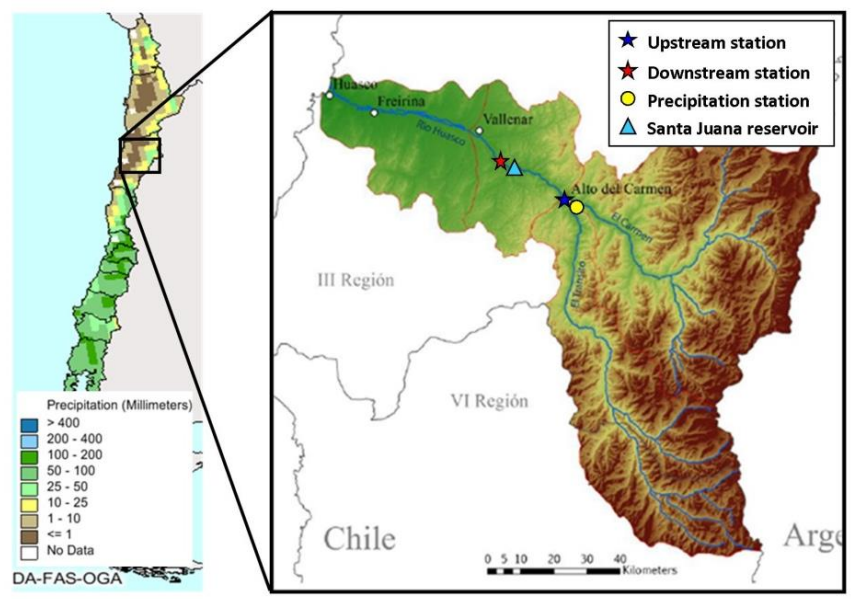

Figure 1: Huasco basin: a) identified on a map of annual precipitation of Chile (DA-FAS-OGA); b) topographical map of the basin (Wagnitz et al., 2014; Fig.1).

The region experiences wet and dry seasons with $80 \%$ of annual precipitation occurring during the wet season, Chilean winter (May - August) (Figure 2). The precipitation is inter-annually variable with the El Niño-Southern Oscillation (ENSO) (Montecinos et al., 2000; Gascoin et al., 2011). During El Niño events, positive rainfall anomalies can be observed, whereas below normal conditions are more likely to occur during La Niña (Verbist et al., 2010; Meza, 2013; Robertson et al., 2014). Winter periods are most vulnerable to these anomalies. Throughout the basin precipitation is unevenly distributed, showing a clear altitude gradient with more precipitation occurring in the mountains. In the basin, precipitation occurs almost exclusively as snowfall, and it is not uncommon for stations in the lower valley to receive no precipitation in a given year. Peak precipitation (midwinter, July) is not seen directly in the discharge data, suggesting the dominance of glacier and snowmelt in the discharge (peak observed in early summer, December) (Figure 2). 
Earth Syst. Dynam. Discuss., doi:10.5194/esd-2016-57, 2016

Manuscript under review for journal Earth Syst. Dynam.

Published: 16 November 2016

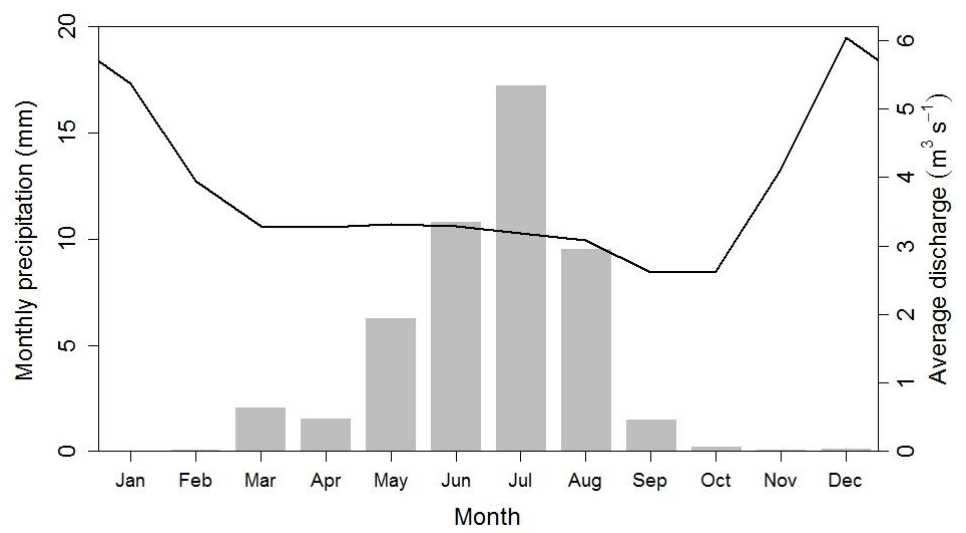

Figure 2: Seasonality plots for monthly precipitation and discharge using daily data (1965-2013).

\subsection{Huasco and water management}

An increasing water demand from different water sectors (agriculture, mining, and domestic water usage) has increased pressure on available water (Gascoin et al., 2011) and its management. The Santa Juana dam, with a capacity of $170 \mathrm{Mm}^{3}$, was built in the basin in 1995 and was in operation by 1998. It is the main regulating water structure in the basin, with the purpose of increasing irrigation security for downstream users. The Huasco basin has been recently managed (2005-2015) by the "Junta de Vigilancia de Río Huasco y sus Afluentes" ("Huasco River and its tributaries surveillance board"), which is monitoring and modelling to calculate water allocations/restrictions. Recent management and restrictions have been established with the objective to limit impacts of hydrological droughts across the basin. Regulations on water use depend upon the reservoir levels (Figure 3a). During the recent multi-year drought (2007-2015), by 2011 reservoir levels dropped below levels of "partial failure" ( $<100 \mathrm{Mm}^{3}$, Figure 3) resulting in the Huasco River Supervisory Board implementing severe water restrictions (through its operational model).
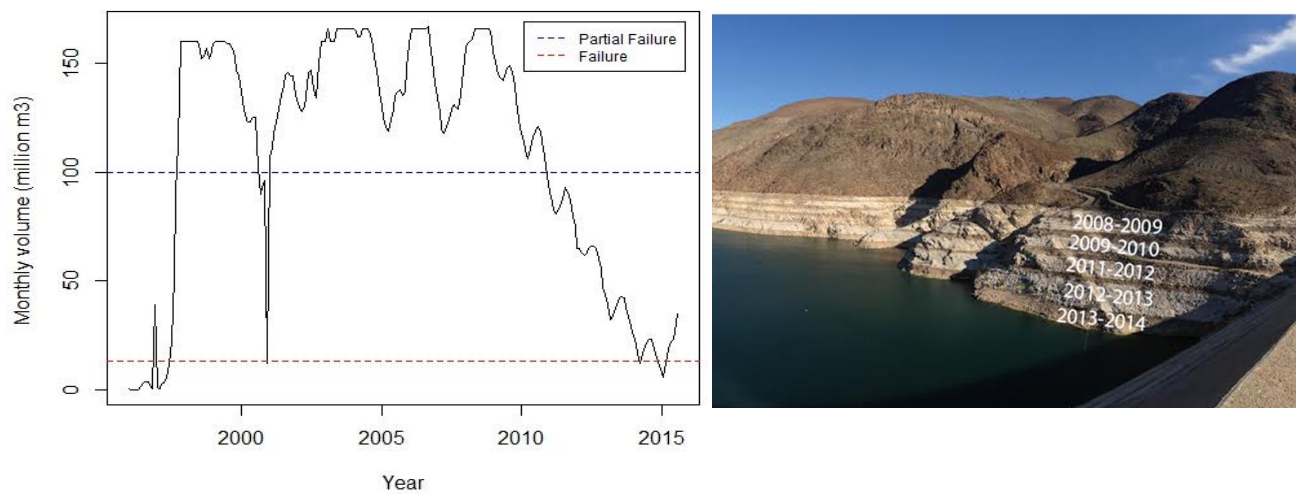

Figure 3: The Santa Juana dam in the Huasco basin, built by 1998: a) reservoir levels with failure thresholds; b) Photograph of the reservoir levels during the recent multi-year drought in Chile starting in 2007 (photo taken May 2014, Huasco Departmento Técnico report, 2014 Figure 7, page 42). 
Earth Syst. Dynam. Discuss., doi:10.5194/esd-2016-57, 2016

Manuscript under review for journal Earth Syst. Dynam.

Published: 16 November 2016

(c) Author(s) 2016. CC-BY 3.0 License.

\section{Methods} In this study, both observation streamflow discharge data $\left(Q_{o b s}\right)$ and modelled discharge data $\left(Q_{\text {sim }}\right)$ were analysed for drought events and characteristics. An upstream-downstream approach was used on the $Q_{o b s}$ to directly compare undisturbed (pre-dam) and disturbed (post-dam) data from the presence of the Santa Juana dam (Section 3.1). By using a station upstream and downstream of the dam, a direct comparison about the changes occurring between the two stations can be made (e.g. similar to López-Moreno et al., 2009; Wu et al., 2009). Based on existing ideas and methods, we use the upstream-downstream approach as a new approach for quantifying change (Section 3.4). The dam started operation by 1998 , therefore this was a break point dividing the time series into preand post-dam periods for the analysis. Modelled data was used to compare simulated discharge data from a naturalised scenario (without the dam, $\mathrm{Q}_{\text {sim-nat }}$ ) and a human-influenced scenario (with the dam, $\mathrm{Q}_{\text {sim-hum }}$ ) at the same station, downstream (Section 3.2). Two different drought analysis methods were implemented on both types of data: the threshold level (TL) method (Section 3.3.1) and standardised indices (SI) (Section 3.3.2). A comparison of the different methods and data enabled an assessment of the results quantifying the impact of the dam on hydrological droughts downstream (Section 3.4). Data analysis was conducted in the open-source software R using packages including $\mathrm{SCl}$, xts, HydroTSM, and hydroGOF.

\subsection{Observation data}

The observation data for this study were daily precipitation and discharge covering the time period of 1965 - 2013 (Table 1). Data was obtained from the Chilean government's General Water Direction (Dirección General de Aguas, DGA). Missing data was less than $5 \%$, and missing data for hydrological records were replaced by linear interpolation (Hisdal et al., 2004), whereas missing data for the meteorological record were replaced with zeros (Jolly \& Running, 2004). Available station data for analysis were limited by their data quality and time lengths. One precipitation station was analysed for meteorological droughts and two discharge stations for hydrological droughts, one upstream and one downstream of the Santa Juana dam (Table 1; Figure 1). However, the focus of this study is on hydrological droughts.

An upstream-downstream approach was used to make a direct comparison between hydrological drought events at both stations (Figure 4). It is known that the exploration of streamflow discharges and the severity and frequency of hydrological droughts in upstream $\left(Q_{\text {obs-up }}\right)$ and downstream $\left(Q_{\text {obs-down }}\right)$ stations is helpful to the understanding of the influence of human activities and its consequences during low-flow periods (López-Moreno et al., 2009; Wu et al., 2009). A baseline period ("undisturbed") from 1965 to 1997 was used as a reference period to indicate the situation before the onset of the significant anthropogenic alternation of the flow, the introduction of the dam by 1998. This is a similar approach to Wang et al. (2009) and Liu et al. (2016). The undisturbed period can also be considered as the "natural" situation, whereas the disturbed period downstream can be considered as the "human-influenced" situation.

\subsection{Modelled data}

The modelled data used here consisted of simulated monthly discharge at the downstream station generated using the Water Evaluation And Planning (WEAP) model for two scenarios (1960 - 2010): 1) "naturalised" with no dam present (also known as "pristine" or "undisturbed" scenario), and 2) "human-influenced" where the Santa Juana dam was present throughout the simulation period. This method is based on the observation-modelling framework presented by Van Loon and Van Lanen 
(2013). The modelled discharge was used as input for the drought analysis (Figure 4), which was at the monthly timescale. The naturalised scenario in the basin allowed a comparison with the humaninfluenced scenario, with the only difference being the dam, therefore providing a direct assessment of the human activity.

The WEAP model is a well-used tool for integrating water resources planning (e.g. Purkey et al., 2008; Mutiga et al., 2010; Mounir et al., 2011). The model was set up for the Huasco basin using 50 years of historical data as inputs: monthly mean temperature, discharge and precipitation data from the DGA. The model includes the water demands of the agricultural, industrial, urban and mining sectors in the basin. WEAP model accuracy was assessed through the Nash-Sutcliffe model efficiency coefficient (NSE), commonly used to assess the predictive power of hydrological models (Nash \& Sutcliffe, 1970). Monthly $\log Q_{\text {obs }}$ and $\log Q_{\text {sim }}$ were compared to see how well the model reproduced observed flow, where a maximum value of +1 indicates a perfect match between model and observations.

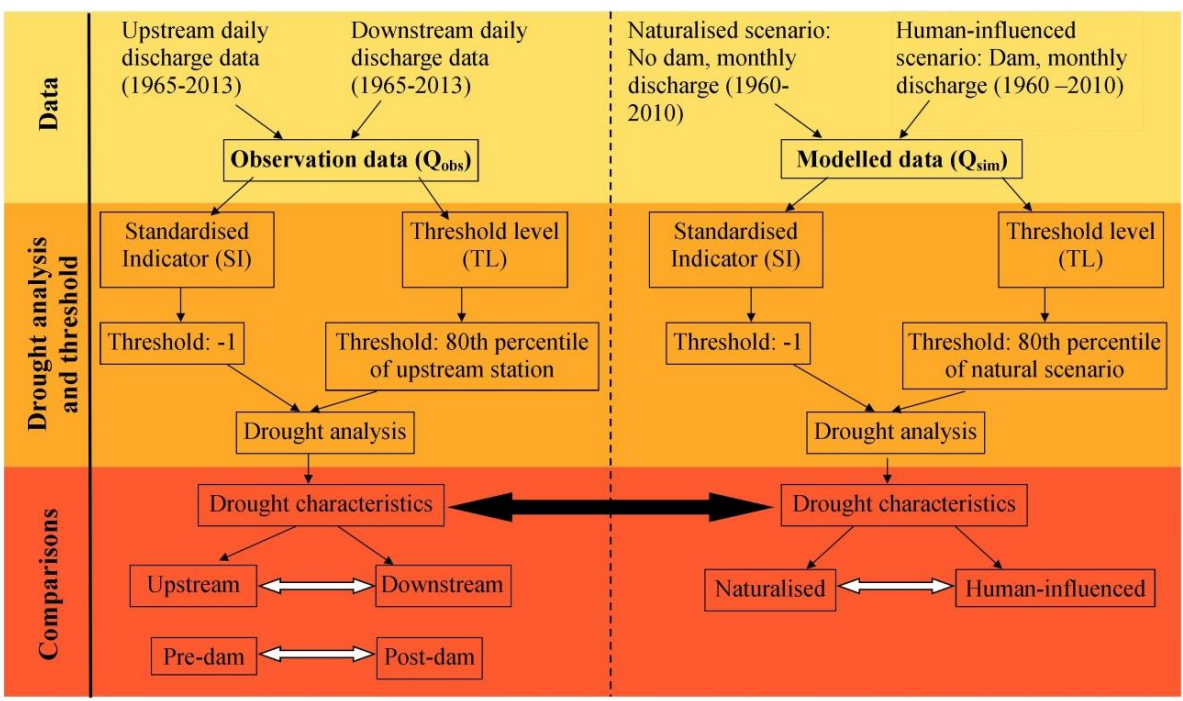

Figure 4: Flow diagram to illustrate the data (yellow) and methods of data analysis (orange) used in this study to then allow for a comparison of hydrological drought characteristics (red).

\subsection{Drought analysis approaches}

Drought events and characteristics were identified and assessed using the common threshold level (TL) method, or through the standardisation of data into regularly used drought indices, standardised indices (SI, Tallaksen \& Van Lanen, 2004; Vicente-Serrano et al., 2004; Van Loon, 2015). Drought event characteristics such as timing, duration and severity were extracted from both the $\mathrm{Q}_{\mathrm{obs}}$ and $\mathrm{Q}_{\text {sim }}$ using the $\mathrm{SI}$ and the TL methods (Figure 4). The term 'severity' is used throughout to refer to the deficit volumes produced by the TL method. However, as SI methods do not generate 
Earth Syst. Dynam. Discuss., doi:10.5194/esd-2016-57, 2016

Manuscript under review for journal Earth Syst. Dynam.

Published: 16 November 2016

(c) Author(s) 2016. CC-BY 3.0 License.

\subsubsection{Threshold level}

Drought events can be identified as periods during which the data (river flow, precipitation, etc) are below a certain threshold, known as threshold level (TL) method (Yevjevich, 1967). The TL method is a frequently applied quantitative drought definition. Thresholds based on percentiles of the flow duration curve are commonly employed, with a recommended threshold of between the $70^{\text {th }}$ and $90^{\text {th }}$ percentile for a daily or monthly time series (Van Loon, 2015). The $80^{\text {th }}$ percentile $\left(Q_{80}\right)$ is frequently used as the threshold for determining a drought (Hisdal \& Tallaksen, 2000; Fleig et al., 2006; Heudorfer \& Stahl, 2016). $Q_{80}$ is derived from the flow duration curve and is the streamflow value which is equalled or exceeded for $80 \%$ of the time. In semi-arid/arid regions, $Q_{50}$ can be used to avoid threshold values of zero (Van Huijgevoort et al., 2012; Giannikopoulou et al., 2014).

When using the TL method, a fixed or variable threshold can be applied to study the deviation from normal runoff, the anomalies (Tallaksen et al., 1997; Hisdal \& Tallaksen, 2000; Fleig et al., 2006). The study region has strong seasonality in its precipitation regime (Figure 2) and it is common to find extended dry periods up to several months where no monthly precipitation is observed (Favier et al., 2009; Verbist et al., 2010; Meza, 2013), therefore the variable threshold was used for the meteorological drought analysis. The variable threshold at the $50^{\text {th }}$ percentile was only used on precipitation data to determine meteorological droughts to avoid a threshold of zero. Given the limited seasonality in the discharge data (Figure 2), and because there are no direct comparisons between the precipitation and discharge data, a fixed threshold was used for the hydrological drought analysis, at the $80^{\text {th }}$ percentile.

Droughts can be mutually dependent, where periods of prolonged low discharge are interrupted by short excess periods, which indicates that the system has not had chance to recover from its deficit. Pooling can be applied in order to merge these mutually dependent events and define an independent sequence of droughts (Tallaksen, 2000; Hisdal \& Tallaksen, 2000). Here, the inter-event criterion method (Zelenhasić \& Salvai, 1987) was used to pool mutually dependent droughts. Optimum inter-event time depends on the regime of the river and the climate of the region (Fleig et al., 2006). The inter-event time period of 15 days was applied based on the sensitivity curve of mean durations at different inter-event time steps that was conducted, as done by Fleig et al. (2006). Minor drought events, which are events of short duration and small deficit volume, can be removed from the analysis using a defined minimum duration. Minor droughts of less than 15 days were excluded from the analysis (as done by Van Loon \& Van Lanen, 2013). The TL analysis on monthly data did not require pooling or minor drought events to be dropped as only drought events greater than one month were identified.

Here, the TL method used the "natural", undisturbed period threshold on the humaninfluenced situation to allow a direct comparison of the impact of the human activity on hydrological droughts. The analysis on the $\mathrm{Q}_{\mathrm{obs}}$ using the TL method used the pre-dam period upstream data as a reference period to represent the "natural" situation, undisturbed (Figure 4). This was used to calculate the fixed threshold at the $80^{\text {th }}$ percentile, which was then applied to both the upstream and downstream data for the whole time period, as done by Liu et al. (2016). For the TL analysis of the $\mathrm{Q}_{\text {sim }}$ data, the $80^{\text {th }}$ percentile of the "naturalised" scenario was used as the threshold for both the naturalised and the "human-influenced" situation drought analysis (Figure 4).

\subsubsection{Standardised Indices}

Drought indices are commonly used to assess drought conditions and characteristics based on the measure of deviation from the normal (Stagge et al., 2015) quantifying the number of standard 
Earth Syst. Dynam. Discuss., doi:10.5194/esd-2016-57, 2016

Manuscript under review for journal Earth Syst. Dynam.

Published: 16 November 2016

(c) Author(s) 2016. CC-BY 3.0 License.

deviations that an observed value is from the 'normal' value that is calculated over a certain time period. The Standardised Precipitation Index (SPI) (McKee et al., 1993) is an indicator for meteorological drought calculated with precipitation data. The process of transforming accumulated precipitation to the standard normal distribution requires the fitting of a univariate probability distribution, which is often the gamma distribution, also used here. Through this normalising, accumulated precipitation can be compared objectively in different climates (Stagge et al., 2015). The SPI is designed to quantify precipitation deficits on multiple timescales ( $3-48$ months). Here, the SPI is calculated on the 6 month time period (SPI-6) as this is known to be effective in showing precipitation over distinct seasons (WMO, 2012; Kingston et al., 2015). The SPI over the 12 month accumulation period (SPI-12) is also used as it is known to perform better in arid climates. Calculated in a similar manner, the Standardised Streamflow Index (SSI) (also known as the Standardised Runoff Index, SRI, Shukla \& Wood, 2008) is an indicator for hydrological drought using streamflow data (Svensson et al., 2015; Barker et al., 2016). The SSI uses an accumulation period of 1 month as its timescale (e.g. Vicente-Serrano et al., 2012; Barker et al., 2016).

The standardised indicator ( $\mathrm{SI}$ ) method standardises each data point according to the time series norm using a pre-determined threshold to represent drought. For both the SPI and SSI the commonly used value of -1 was implemented, where values below this represented drought conditions (McKee et al., 1993; Lloyd-Hughes \& Saunders, 2002). The SI method produced monthly values which were analysed for drought event characteristics (dates, duration, maximum intensity). SI maximum intensity represented the lowest standardised value of the drought event (Spinoni et al., 2014) from the data mean (zero).

\subsection{Estimation of the human impact on drought characteristics} The frequency of drought events, mean and maximum duration, and mean and maximum severity (deficit or intensity) were obtained through the different drought analysis methods on the $Q_{\text {obs }}$ and $\mathrm{Q}_{\text {sim. }}$. Comparisons are made within and across methods and data. With the $\mathrm{Q}_{\mathrm{obs}}$ results, a comparison between the upstream and downstream stations was made, looking at the pre- and post-dam period (Figure 4). A similar approach has been used by López-Moreno et al. (2009) to study the transboundary impact of a Spanish/Portuguese reservoir. With the $Q_{\text {sim }}$ results, the naturalised and human-influenced scenarios at the downstream station were compared (Figure 4). For each drought characteristic, an estimation of the human impact on hydrological drought was estimated using the following equations.

\subsubsection{Percentage change due to human influence in observation data}

For the $\mathrm{Q}_{\mathrm{obs}}$ data, to establish the overall percentage change due to human influence with the upstream-downstream approach, a two stage method was used. In the first step, the natural difference between the upstream and downstream stations was quantified for the same time period (Eq 1). These results report the percentage change showing the natural propagation relationship from upstream to downstream during the pre-dam period, and then the affected propagation during the post-dam period due to the human influence. Percentages reported are the change downstream $\left(Q_{\text {down }}\right)$ relative to upstream $\left(Q_{u p}\right)(E q 1)$.

$\%$ of change downstream $=\left[\left(Q_{\text {down }}-Q_{\text {up }}\right) / Q_{\text {up }}\right] * 100$

[Equation 1] 
Earth Syst. Dynam. Discuss., doi:10.5194/esd-2016-57, 2016

Manuscript under review for journal Earth Syst. Dynam.

Published: 16 November 2016

(c) Author(s) 2016. CC-BY 3.0 License.

In the second step, this natural difference was accounted for and used to establish one overall value for the percentage of human influence during the human-influence period (post-dam). The pre-dam period relationship established the percentage difference between the two situations (Eq 1) and was then used to calculate an expected value for the "natural" situation post-dam downstream, based on the percentage change and the $Q_{\text {obs-up }}$ value post-dam. This generates an expected "natural" value for the post-dam period which could be directly compared to the actual $\mathrm{Q}_{\mathrm{obs} \text {-down }}$ post-dam value. The difference between this expected value ( $\left.\operatorname{Exp}_{\text {hum }}\right)$ and the actual observed value $\left(\mathrm{Obs}_{\text {hum }}\right)$ gave an overall percentage of human influence in the post-dam period (Eq 2).

$\%$ of human influence $=\left[\left(\mathrm{Obs}_{\text {hum }}-\operatorname{Exp}_{\text {hum }}\right) / \operatorname{Exp}_{\text {hum }}\right] * 100$

[Equation 2]

\subsubsection{Percentage change due to human influence in modelled data}

For the $\mathrm{Q}_{\text {sim }}$ data, the percentage change due to human influence only needed a direct comparison of $Q_{\text {sim-nat }}$ and $Q_{\text {sim-hum }}$ at the downstream station (Eq 3). This could be calculated for the whole time period, or separated into the pre-dam and post-dam periods for a direct comparison with $\mathrm{Q}_{\text {obs }}$ results. Percentages reported are the change between the natural and the human situation, relative to the natural one. $Q_{\text {hum }}$ represents human situation, $Q_{\text {nat }}$ represents the natural situation.

$\%$ of human influence $=\left[\left(Q_{\text {hum }}-Q_{\text {nat }}\right) / Q_{\text {nat }}\right] * 100$

[Equation 3]

\section{Results and discussion}

\subsection{Drought characteristics in observation data}

Meteorological and hydrological droughts from the observation data were identified using the SI and TL methods. Visually, the SI results show similar meteorological drought events pre- and post-dam (Figure 5a), whereas the hydrological droughts are much more severe pre-dam due to the major event in 1968-1972, known as 'The Great Drought of 1969' in Chile (Figure 5). Similarly, in the TL data, hydrological droughts appear much worse in the pre-dam period (Figure 6), and within this period downstream hydrological droughts seem to propagate into slightly worse events than upstream (Figure 6b). The differences between meteorological and hydrological droughts reflect the propagation from meteorological to hydrological drought. However, after completion of the dam by 1998 , hydrological drought events appeared to be reduced in their frequency and duration, especially downstream of the dam (Figure 6). Although similar meteorological droughts occurred during the post-dam period (e.g. 2004, 2006, 2012), they did not propagate into severe hydrological droughts during the post-dam period downstream like The Great Drought pre-dam (Figure 5 \& 6). Furthermore, a delay of the drought events can be seen after the building of the dam between the upstream and downstream SSI (Figure 5b) with droughts downstream occurring later in the year than upstream, by roughly 8 months. This temporal difference between observed droughts upstream and downstream reflects the impact of human activities, also observed in other studies (Assani et al., 2013; Liu et al., 2106).

Quantitative analysis on drought characteristics using SI and TL methods confirms this first assessment of the results, with nearly all drought characteristics reduced due to the presence of the dam (\% human influence) (Table $2 \& 3$ ). The only exception was maximum duration where an increase (+25\%) was seen in the SSI (Table 2). The SSI showed that on average, drought events downstream were twice as long as upstream pre-dam (+113\%), whereas during the post-dam period 
Earth Syst. Dynam. Discuss., doi:10.5194/esd-2016-57, 2016

Manuscript under review for journal Earth Syst. Dynam.

Published: 16 November 2016

(c) Author(s) 2016. CC-BY 3.0 License.

they became shorter downstream (-13\%) translating into reduction of over a half due to human influence (-59\%) (Table 2). TL method also showed this pattern post-dam (-55\%), although drought durations were already shorter downstream pre-dam in the TL method (-23\%), resulting in an overall estimated decrease of $-42 \%$ because of human influence (Table 3 ).

A decrease in average and maximum severity (intensity and deficit) due to introduction of the dam was seen in both the SSI and TL results, with minor changes seen in the SSI results (Table 2), but major changes observed in the TL results (Table 3 ). This was even seen in TL results when maximum deficit was seen to be larger downstream during the pre-dam period $(+28 \%)$, yet during the post-dam period maximum deficit was seen to be reduced largely downstream (-78\%), resulting in an $83 \%$ decrease overall due to the human influence (Table 3). Yet, in the SSI, no change was found between pre- and post-dam in upstream and downstream maximum intensity (Table 2). These discretions in directions and magnitudes of results are explored further in Section 4.4.

With regards to the meteorological drought, although results show similar events pre- and post-dam, there are uncertainties regarding the use of standard indicators and regularly applied methods in regions of limited precipitation. It is important to note that the SPI for meteorological droughts should be used with caution in arid regions because it has a poor performance with near zero precipitation (Van Huijgevoort et al., 2012). From our study, we can confirm that SPI is not the best method to quantify meteorological drought in arid climates like Chile, resulting in unexpected blocky patterns (Figure 5a). One possible solution to this limitation is to use the consecutive dry period method (CDPM) (also known as consecutive dry days, CDD), or the newer approach suggested by Van Huijgevoort et al. (2012) which combines CDD with the variable TL, to disentangle normal dry periods from drought events. 
Earth Syst. Dynam. Discuss., doi:10.5194/esd-2016-57, 2016

Manuscript under review for journal Earth Syst. Dynam.

Published: 16 November 2016

(c) Author(s) 2016. CC-BY 3.0 License.

a)
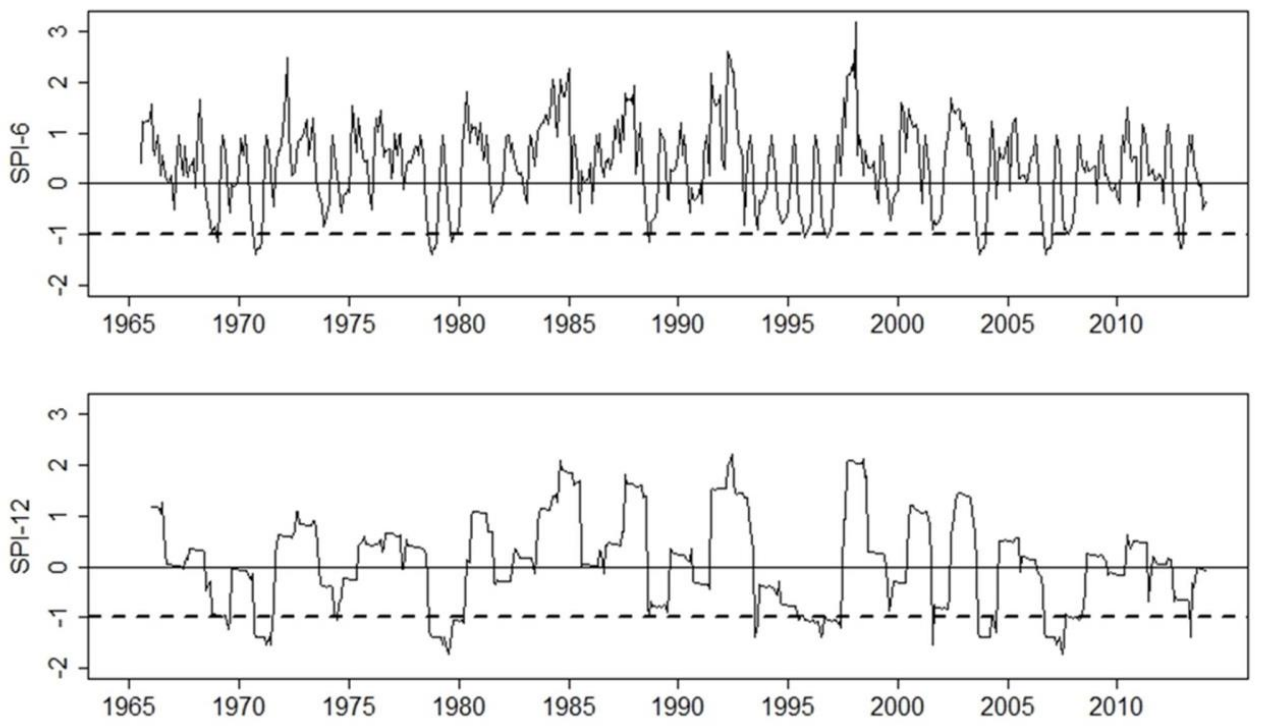

b)

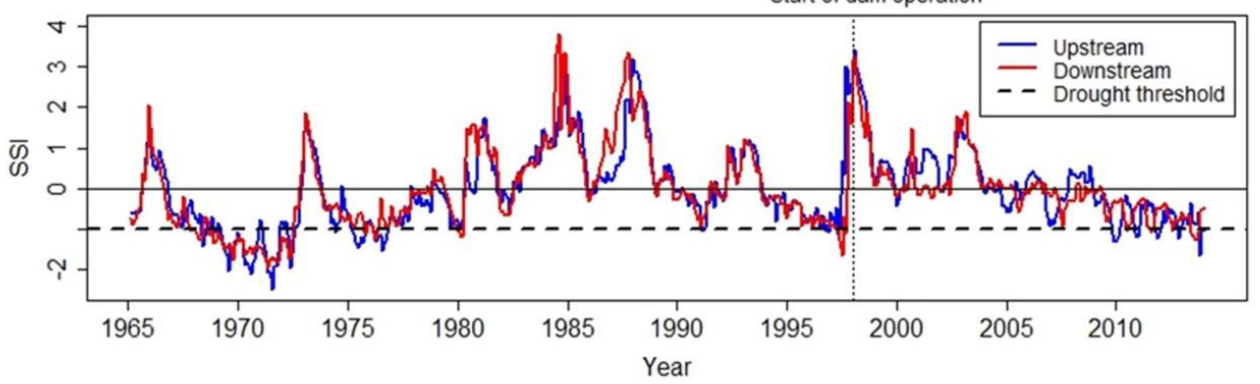

Figure 5: Standardised Indices method results for meteorological and hydrological droughts, a) SPI-6 and SPI12 and b) SSI for the upstream and downstream stations (1965 - 2013). The threshold of -1 was used to identify drought events. The introduction of the dam is indicated on the SSI plot. 
Earth Syst. Dynam. Discuss., doi:10.5194/esd-2016-57, 2016

Manuscript under review for journal Earth Syst. Dynam.

Published: 16 November 2016

(c) Author(s) 2016. CC-BY 3.0 License.
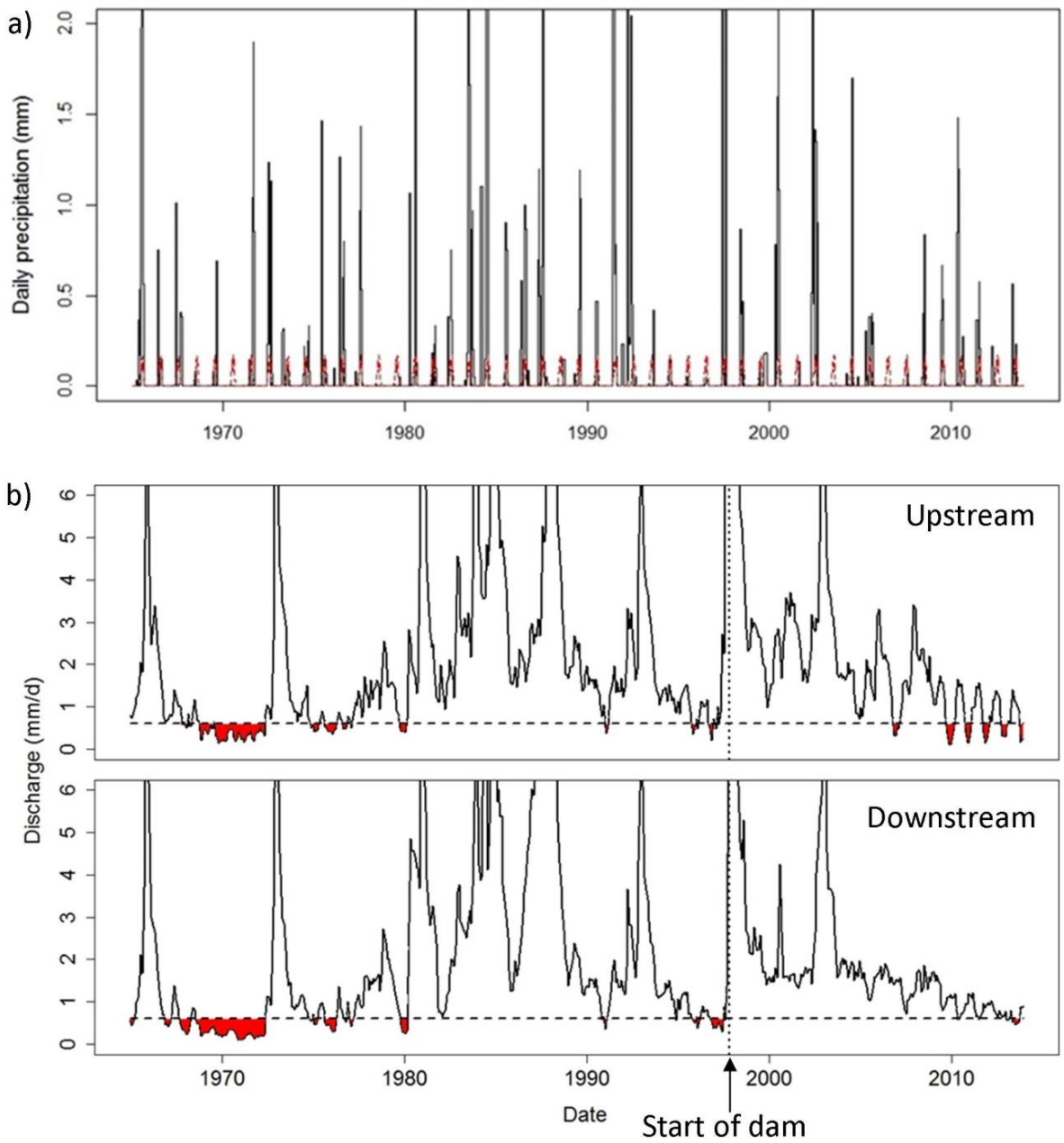

Figure 6: Threshold level method results. a) Variable threshold level method $\left(Q_{50}\right)$ drought analysis on precipitation observation data. b) Fixed threshold level method $\left(Q_{80}\right)$ drought analysis on upstream and downstream observation data. Monthly data is plotted here for a clearer visual. The upstream $\mathrm{Q}_{80}$ threshold is indicated with the horizontal dotted line, and the timing of the dam in operation is highlighted by the vertical dotted line.

\subsection{Drought characteristics in modelled data}

The WEAP model reproduced observed flows well, as indicated by relatively good model efficiency, quantified with the Nash-Sutcliffe model efficiency coefficient, NSE (Nash \& Sutcliffe, 1970). The $\mathrm{Q}_{\text {obs-down }}$ pre-dam period (1965-1997) was compared with the $\mathrm{Q}_{\text {sim-nat }}$ data for the same time period, giving a "Natural" NSE of 0.817. The $\mathrm{Q}_{\text {obs-down }}$ post-dam period (1998-2010) was compared with the $\mathrm{Q}_{\text {sim-hum }}$ data for the same time period, giving a "Human-influenced" NSE of 0.454.

Drought analysis of the WEAP model outputs shows that the presence of the dam changed the characteristics of drought events in the basin. Unlike the $Q_{\text {obs }}$ result (section 4.1), the TL method 
Earth Syst. Dynam. Discuss., doi:10.5194/esd-2016-57, 2016

Manuscript under review for journal Earth Syst. Dynam.

Published: 16 November 2016

(c) Author(s) 2016. CC-BY 3.0 License.

on the $\mathrm{Q}_{\text {sim }}$ showed that the WEAP model simulated at least twice as many drought events in the scenario with a dam than the naturalised scenario (+100\%) (Table 4), but a decrease in the rest of the drought characteristics was seen with this analysis, including a halving of average duration and deficit volumes with the presence of the dam, but having less reduction on maximum deficit and duration (Table 4). These results imply that the dam would have more of an impact on reducing average drought events, but not major ones (shown by less reduction on maximum characteristics results). SI results show less difference with the presence of the dam, and the results were not in full agreement with the magnitude and direction of change identified by the TL method. A reduction in the number of events was seen with the presence of the dam (-20\%), and slightly shorter durations on average $(-12 \%)$ but no change to the maximum duration, and similar average maximum intensities (+2\%) (Table 4).

One large change in the hydrological system with the presence of the dam is the timing of discharge peaks and drought events, also observed in the $Q_{\text {obs }}$ data (Figure 5 \& 7). A delay in the timing of drought events can be seen between the naturalised and the human-influenced scenarios (Figure 7). $\mathrm{Q}_{\text {sim-nat }}$ had only spring and summer droughts, whereas $\mathrm{Q}_{\text {sim-hum }}$ had mainly winter droughts. In both, spring and summer hydrological droughts were found in the upstream and naturalised scenario, whereas winter droughts were mainly seen in the downstream (post-dam) and human-influenced scenario. This shift in the timing of droughts due to human-influences is an important deviation from the natural system as it can have implications on ecosystem response and resilience to drought, especially in arid climates where ecosystems are already sensitive to small changes in precipitation and available water (Fiebig-Wittmaack et al., 2012). These results are in agreement with existing studies which found that reservoirs modify the hydrologic regime of rivers, producing a delay of the natural annual cycle of river and provide a buffering capacity (Petts \& Gurnell, 2005; López-Moreno et al. 2009; Assani et al., 2013) due to increased storage. This anthropogenic alteration of river regime demonstrates the main management principle of reservoirs: designed to store water in the wet season and increase water availability for the dry season, if operated for water supply (Wanders \& Wada, 2015), helping build resilience in the system against drought impacts and hydrological variability (AghaKouchak et al., 2016). 
Earth Syst. Dynam. Discuss., doi:10.5194/esd-2016-57, 2016

Manuscript under review for journal Earth Syst. Dynam.

Published: 16 November 2016

(c) Author(s) 2016. CC-BY 3.0 License.
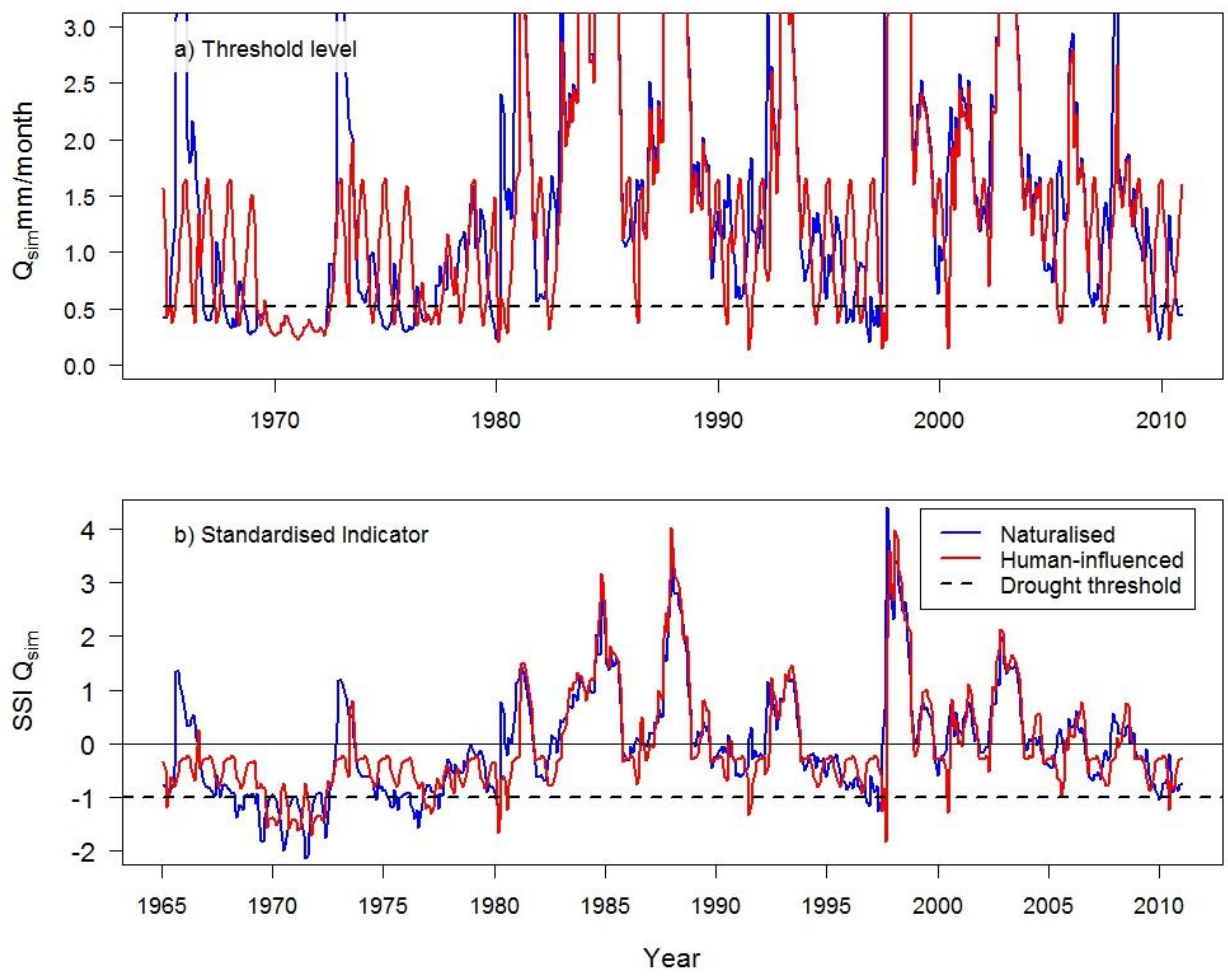

Figure 7: Monthly discharge time series for WEAP scenario outputs used for drought analysis with the naturalised (without reservoir, blue) and human-influenced (with reservoir, red) scenarios (1965 - 2010). a) Drought threshold of Q80 for the naturalised scenario is used (dotted line) for the threshold level method drought analysis on both scenarios; b) Standardised indicator (SSI) with the threshold of -1 for both scenarios.

\subsection{Comparison between observed and modelled data}

Overall, a decrease in drought characteristics during the post-dam period was seen downstream in this study (Table 5), but with some disagreements across particular methods and data. Using the direction and magnitude of change calculated amongst the drought characteristics (Tables 2 \& 3), the two different methods of drought analysis (SI and $\mathrm{TL}$ ), and the two different data sources $\left(\mathrm{Q}_{\mathrm{obs}}\right.$ and $\left.\mathrm{Q}_{\text {sim }}\right)$ can be compared for pre-dam and post-dam periods (Table $5 \& 6$ ). $\mathrm{Q}_{\text {obs }}$ gave the same direction of change for half of the drought characteristics results when cross checking the $\mathrm{SI}$ and $\mathrm{TL}$ methods (5/10 results had the same direction, Table 5), which is more than the $Q_{\text {sim }}$ results ( $3 / 10$ agreement, Table 5). The frequency of drought events in the human-influenced scenario was simulated to be over twice that of the naturalised scenario, which is the opposite pattern to that of $\mathrm{Q}_{\mathrm{obs}}$ which saw a decrease in drought frequency with the presence of the dam.

The differences between the $Q_{\text {obs }}$ and $Q_{\text {sim }}$ results could be due to limitations in the WEAP model. Despite the relatively high NSE values, the WEAP model might have issues simulating river flow correctly, especially during the human-influenced period (post-dam) as indicated by the lower 
Earth Syst. Dynam. Discuss., doi:10.5194/esd-2016-57, 2016

Manuscript under review for journal Earth Syst. Dynam.

Published: 16 November 2016

(c) Author(s) 2016. CC-BY 3.0 License.

Nash-Sutcliffe value (Human NSE) and the disagreement in the directions of change compared to the $\mathrm{Q}_{\text {obs }}$ results (Table $5 \& 6$ ). This may be because variations in water use in the basin are not simulated correctly, which would be especially prominent in the post-dam period where water use restrictions are implemented based on reservoir levels. These restrictions are not represented in the scenario modelling, and therefore this may explain the difference between the data and the lower Human NSE value. Furthermore, other human activities (i.e. demand)in the basin not focused on, such as land cover and land use change, are likely to have generated some difference between $\mathrm{Q}_{\mathrm{obs}}$ and $\mathrm{Q}_{\text {sim }}$ (Liu et al., 2016). The response and feedback of human actions to drought and variable water availability (such as the regulation of water use dependent upon the reservoir levels) is an important aspect that needs to be accounted for and further investigated (e.g. Kuil et al., 2016).

\subsection{Comparisons across the different drought analysis methods}

The direction of change was mixed across the drought characteristics for the different methods (Table 5), but the TL method clearly gave the most agreement on the results between $\mathrm{Q}_{\text {obs }}$ and $\mathrm{Q}_{\text {sim }}$ (8/10 same direction, Table 5) compared to SI method (3/10 agreement, Table 5). For the overall percentage of human influence in the post-dam period, both methods only have less than half of the results agreeing on the direction of change (2/5 agreeing, Table 6$)$.

An assessment of the application of different methods and data for drought analysis has been made based on the results of this study. The two different drought analysis methods for hydrological drought analysis (SI and $\mathrm{TL}$ ) were conducted here in the way they are most commonly used in the literature. The results generated with these typical methods consequently differed substantially (Section 4.3). The SI method had the commonly-used threshold of -1 on monthly data and included the whole time period to determine drought events, whereas the TL method used the commonly-applied fixed threshold of the $80^{\text {th }}$ percentile on daily data based on a reference period of "undisturbed" data (1965-1997). Five fundamental differences in the calculations between the two methods could help to explain the deviation and disagreement in the results seen in this study. The aim of this paper is not to directly compare between the SI and TL method, but to find the most appropriate method for analysing the human impact on drought.

Firstly, the $\mathrm{SI}$ threshold of -1 is not the equivalent to $Q_{80}$ used in the TL method, therefore potentially detecting different drought events between the two methods. The $80^{\text {th }}$ percentile is closer to the $\mathrm{SI}$ threshold of -0.8 . The effect is assumed to be small, as previous studies have found that changing the threshold level slightly changes the numbers, but not the direction of change (e.g. Van Loon \& Van Lanen, 2013; Heudorfer \& Stahl, 2016), however a direct comparison of a -1 and -0.8 threshold would likely not result in the same number of drought events. Secondly, here a fixed threshold for the TL was used, whereas the $\mathrm{SI}$ is more comparable to a variable threshold because it calculates the anomaly compared to the climatology of the same month. Heudorfer and Stahl (2016) recently investigated the impact of a threshold choice on results, finding that it changed the distribution of drought durations, with a substantial increase seen in the frequency of short droughts identified by the variable threshold compared to the fixed and a slight decrease in the number of long droughts.

Third is that the SI method used monthly data, whereas the TL method used daily data. This may influence the frequency of droughts, their duration and severity as the TL method could identify shorter droughts. For example, more hydrological drought events were observed using the TL method than SI (Table 2 \& 3), which could be due to the different timescales used. In the TL method, 
Earth Syst. Dynam. Discuss., doi:10.5194/esd-2016-57, 2016

Manuscript under review for journal Earth Syst. Dynam.

Published: 16 November 2016

(c) Author(s) 2016. CC-BY 3.0 License.

minimum drought event duration of 15 days was used to remove minor droughts, but the monthly data used in SI by default had a minimum duration of 30 days.

Fourthly, the SI method does not use a reference period like the TL method, which is based on a reference period threshold of 1965 - 1997 ("undisturbed"). The advantage of using an "undisturbed" reference period is that it removes the impact of the dam from the threshold/normal, whereas the SI method includes the human-influenced data in the calculation of the normal, and with a different normal different drought events and characteristics are identified (Table 5 \& 6).

Furthermore, the fifth difference is that the SI uses station specific data for the threshold, whereas, TL method used the "natural" station for the threshold to apply to both the "natural" (upstream) and "human-influenced" (downstream) data. Again, this is useful for directly comparing the natural situation to the human-influenced. However, using individual stations such as in the SI method changes the normal against which the droughts are compared, with potentially large consequences on the results.

\subsection{Sensitivity analysis of drought analysis methods}

These results and discussions have shown that although commonly-used drought analyses have been applied ( $\mathrm{SI}, \mathrm{TL})$, the different ways in which it they have been calculated have produced different results. Therefore, a sensitivity analysis of the aforementioned differences was conducted (Table 7). For this, we quantified drought with the original SI method using a threshold of -0.8 , and also a modified TL version which uses the variable threshold at the $80^{\text {th }}$ percentile with the whole time period used to calculate the threshold. Station specific thresholds were used in this modified TL method to simulate the replicate the SI method. The two drought analysis methods were conducted on the same monthly data for consistency.

The direction of change calculated earlier in this study (Table 5 \& 6) can be directly compared with the results of the sensitivity analysis, with strong agreement found, although some differences still emerge, mainly in the duration characteristics (Table 7). This was seen more obviously in the sensitivity analysis for the overall percentage of human influence (Table 8). Looking across the different methods, the largest disagreement in direction of change can be seen in the TL method post-dam (Table 7). Therefore it is seen that by recalculating the threshold including human influences (so same station and whole period), the positive effect of the dam on drought is removed, implying that this could be happening in the SI method.

It can be seen that the decisions made during the drought analysis process (e.g. daily or monthly data, fixed or variable threshold, reference period or whole period for the threshold, upstream/natural or station specific threshold) can affect the results of drought characteristics. This assessment of the different methods and data suggests that the best approach in this application is to use is the TL methods on observation data, due to the flexibility of the method to exclude humaninfluenced time period from the threshold, and using daily data for finer resolution of results. Using this suggestion, we can report the $T L Q_{\text {obs }}$ results with confidence, a reduction in all drought characteristics downstream with the presence of the Santa Juana dam, with large reductions in the average duration and deficit volumes of droughts in the post-dam period (Table $3,5 \& 6)$. The impact of the dam was especially seen in drought deficit volumes which showed major reductions compared to upstream data in the post-dam period and the expected results based on the pre-dam propagation relationship (Table 3). 
Earth Syst. Dynam. Discuss., doi:10.5194/esd-2016-57, 2016

Manuscript under review for journal Earth Syst. Dynam.

Published: 16 November 2016

(c) Author(s) 2016. CC-BY 3.0 License.

\subsection{Specific major drought events in the basin}

Here we focus on two major drought events in the time series to explore the observed impact and modelled impact of the dam on drought characteristics downstream, one during the pre-dam period, The Great Drought (1968-69), and one in the post-dam period, the recent multi-year drought (2007-2015).

The Great Drought of 1968-69 was an event with some of the largest deficits across the country during the twentieth century (seen in Figure 6b). The impacts were felt across the region with huge losses for crops (potato, rice, maize, beans), fruit trees, and vineyards, livestock died, and associated milk, meat and wool outputs declined. In the Huasco region farmers and communities also lacked water for human consumption. Across all the methods and data this was represented as the worst hydrological drought in both duration and severity. Drawing on the recommendations from this study, using the TL method for the drought analysis, the $Q_{\text {obs }}$ results at the downstream station showed the drought event to last 46 months (drought event observed Sept 1968 - May 1972 ) and $Q_{\text {sim }}$ results showed the event to be of similar duration (45 months) in the naturalised scenario. However, $\mathrm{Q}_{\text {sim-hum }}$ results suggested that with the presence of the Santa Juana dam, the event would have been alleviated for the first year (drought event modelled Sept 1969 - July 1972). Therefore, the presence of the dam would have helped to alleviate the start of the drought event, however, it would have not prevented against a major drought fully; according to the simulations, the drought would have still persisted for three years.

More recently, in 2007 a multi-year drought started in Chile, hampering copper production (of which Chile is the world's number one exporter), exacerbating forest fires, driving energy prices higher (due to reduced hydro-power production), and negatively impacting agriculture (Boisier et al., 2016). The effects of the drought were intensified by an increasing demand driven by the country's economic growth; Chile's economy has more than doubled in a decade. The quantity of water stored in reservoirs dropped dramatically during the drought (e.g. Santa Juana dam, Figure 3). Again, just focusing on the recommended TL method, this multi-year drought event was represented in the $\mathrm{Q}_{\text {obs-up }}$ data as series of hydrological events from 2006 until the end of the time period (Figure 6b) whereas in $\mathrm{Q}_{\text {obs-down }}$ the drought events do not occur until 2010, when reservoir levels entered partial failure (Figure 3). Drought events downstream of the dam are clearly much shorter in duration and deficit until the end of the time series (Figure $6 \mathrm{~b}$ ). These results suggest that the presence of the dam has helped to alleviate the recent multi-year drought in the downstream station, postponing the onset of events for the first four years because of the increased storage in the system.

These results have shown that even though reservoirs are seen to have a positive effect in alleviating droughts, they are often not resilient enough to completely protect against large multiyear droughts, although this is partly related to reservoir size and management. Similar to these results, it has also been suggested through socio-hydrological modelling that reservoirs have been seen to result in less frequent drought impacts, but for major drought events where the reservoirs run dry, drought impacts may be much more severe (Kuil et al., 2016). Therefore, it can be argued that other ways to build resilience against these major droughts, other than just increasing and managing storage, are necessary. For example, a large reduction in water consumption in the Australian city of Melbourne was seen to help alleviate the impacts of the Millennium Drought (Low et al., 2015). However, caution should be applied to coping strategies to drought which involve an over-abstraction of groundwater supplies, as this has been seen to worsen droughts, lowering groundwater levels and lengthening recovery time of the groundwater system (Van Loon \& Van Lanen, 2013). 
Earth Syst. Dynam. Discuss., doi:10.5194/esd-2016-57, 2016

Manuscript under review for journal Earth Syst. Dynam.

Published: 16 November 2016

(c) Author(s) 2016. CC-BY 3.0 License.

\section{Concluding remarks}

\subsection{Impact of reservoirs on hydrological droughts}

These results on drought characteristics in the past half a century have not been shown before for this basin, this region, or this topic, therefore providing useful information on drought frequency and characteristics in a vulnerable environment with regard to water resources. This is also the first attempt in the region to quantify the impact of a human activity, the presence of a dam, on hydrological droughts. Overall, in the Huasco basin a decrease in the frequency, duration and severity of drought events was observed downstream of the Santa Juana dam, showing that the presence of a reservoir provides resilience against short-term droughts. However, this study also found that the reservoir could not alleviate fully against major multi-year droughts and therefore it is important to increase resilience in other ways.

A delay in timing of drought events with the presence of the dam was also seen downstream, showing redistribution in water availability solely due to human activities, the regulation of water from the reservoir. It was seen that the reservoir altered the river regime downstream, causing a delay in the timing of hydrological droughts (from spring/summer droughts to winter droughts), which could have an important impacts on ecosystems, especially in sensitive environments such as arid regions. Therefore, it is important to monitor and increase research and understanding of the impact of human activities on the hydrological system, particularly in these semi-arid regions, but also worldwide.

\subsection{Quantifying human influence on droughts: ways forward}

This work highlights the importance of including and assessing the impact of anthropogenic activities into drought analysis. This research has shown how the two methods of analysis used (standardised indices and threshold level) differed, possibly due to the differences between how the different methods include or exclude the human influences in the "normal" situation against which drought is assessed. This work suggests the need for care when choosing data and method for drought analysis, as those decisions are seen here to affect the results. Using an undisturbed reference period, as the threshold level method did here, helps to exclude the human impact from the threshold/ "normal", allowing for more direct conclusions about the human impact during the disturbed period. Whilst the focus of this study was on the impacts of a reservoir on hydrological droughts, other activities such as irrigation, groundwater water abstraction, and urbanisation should also be investigated across different climates, river basins and societal contexts. This work show an effective way forward to quantify the human influence on hydrological droughts, the recommended TL method with an "undisturbed" period for the threshold, that can be applied elsewhere, and on other human activities, to increase our understanding of the impacts of anthropogenic activities on hydrological droughts 
Earth Syst. Dynam. Discuss., doi:10.5194/esd-2016-57, 2016

Manuscript under review for journal Earth Syst. Dynam.

Published: 16 November 2016

(c) Author(s) 2016. CC-BY 3.0 License.

Author contribution: SR and AVL came up with the concept for the manuscript. SR conducted the analysis. SR wrote the manuscript with the input from all co-authors ( $A V L, D H, K V, H M)$. AVL provided continuous input and insight. KV and HM provided access to the data and local information from the basin. The authors would also like to thank the editor for their valuable comments.

Competing interests: The authors declare that they have no conflict of interest.

Acknowledgements: This project was funded by the Dutch NWO Rubicon Project "Adding the human dimension to drought" (reference number: 2004/08338/ALW). The present work was (partially) developed within the framework of the Panta Rhei Research Initiative of the International Association of Hydrological Sciences (IAHS) (see http://iahs.info/Commissions--W-Groups/WorkingGroups/Panta-Rhei/About-Panta-Rhei.do). The authors would like to thank Pablo Rojas and Sergio Alejandro Gutiérrez Valdés at Junta de Vigilancia de Río Huasco y sus Afluentes, Chile for their work on the WEAP model in the Huasco basin. The authors would also like to thank the research group at the University of Birmingham for their discussions and Niko Wanders for his continued support for the ideas and analysis. 
Earth Syst. Dynam. Discuss., doi:10.5194/esd-2016-57, 2016

\section{References}

AghaKouchak, A., Feldman, D., Hoerling, M., Huxman, T., Lund, J. Water and climate: Recognize anthropogenic drought. Nature, 524: $409-411.2015$.

AghaKouchak, A., Mehran, A. \& Mazdiyasni, O. Socioeconomic Drought in a Changing Climate: Modeling and Management, Geophysical Research Abstracts EGU, 18, 2016.

Assani, A., Simard, E., Gravel, E., Ibrahim, G., Campeau, S. The Impact of "Man-Made Hydrological Drought" on Plant Species Abundance in the Low-Flow Channel Downstream from the Matawin Dam, Quebec. Water, 5(3), 875-892, 2013.

Barker, L. J., Hannaford, J., Chiverton, A., Svensson, C. From meteorological to hydrological drought using standardised indicators. Hydrol Earth Syst Sc, 20: 2483 - 2505, 2016.

Basin-info, 2014. Huasco River Basin. http://www.basin-info.net/river-basins/huasco-river-basin-chile

Boisier, J. P., Rondanelli, R., Garreaud, R. D., \& Muñoz, F. Anthropogenic and natural contributions to the Southeast Pacific precipitation decline and recent megadrought in central Chile. Geophys Res Lett, 43(1): 413421, 2016.

Favier, V., Falvey, M., Rabatel, A., Praderio, E., López, D. Interpreting discrepancies between discharge and precipitation in high-altitude area of Chile's Norte Chico region (26-32 ${ }^{\circ} \mathrm{S}$ ). Water Resour Res, 45, W02424, 2009.

Fiebig-Wittmaack, M., Astudillo, O., Wheaton, E., Wittrock, V., Perez, C., Ibacache, A. Climatic trends and impact of climate change on agriculture in an arid Andean valley. Climatic Change, 111(3): 819 - 833, 2012.

Fleig, A. K., Tallaksen, L. M., Hisdal, H., Demuth, S. A global evaluation of streamflow drought characteristics. Hydrol Earth Syst Sc, 10: 535 - 552, 2006.

Gascoin, S., Kinnard, C., Ponce, R., Lhermitte, S., MacDonell, S., Rabatel, A. Glacier contribution to streamflow in the two headwaters of the Huasco River, Dry Andes of Chile. The Cryosphere, 5: 1099-1113, 2011.

Giannikopoulou, A. S., Kampragkou, E., Gad, F. K., Kartalidis, A., Assimacopoulos, D. Drought characterisation in Cyclades complex, Greece. European Water, 47: 31 - 43, 2014.

Heudorfer, B. \& Stahl, K. Comparison of different threshold level methods for drought propagation analysis in Germany. Hydrol Res, 47(4), DOI: 10.2166/nh.2016.258, 2016.

Hisdal, H. \& Tallaksen, L. M. Drought Event Definition. Technical Report No. 6: Assessment of the Regional Impact of Droughts in Europe. Department of Geophysics, University of Oslo, Norway, 2000.

Hisdal, H., Tallaksen, L.M., Clausen, B., Peters, E., Gustard, A. Hydrological Drought Characteristics. In Tallaksen and Van Lanen (eds) 2004, Hydrological Drought: Processes and estimation methods for streamflow and groundwater. Elsevier Science, p. 139 - 198, 2004.

Huasco Departmento Técnico report, 2014. Administración de recursos hídricos de la cuenca del río huasco análisis de oferta y demanda de agua. Aravena, V. G., Valdés, S. G., Torres, P. R. Junta de Vigilancia de la cuenca del río Huasco y sus afluentes, Noviembre 2014. http://www.riohuasco.cl/boletin-hidro-climatico-n8/

Jolly, W. M. \& Running, S. W. Effects of precipitation and soil water potential on drought deciduous phenology in the Kalahari. Glob Change Biol, 10: 303-308., 2004.

Kingston, D.G., Stagge, J.H., Tallaksen, L.M., Hannah, D.M. European-Scale Drought: Understanding Connections between Atmospheric Circulation and Meteorological Drought Indices. J Climate, 28: 505 - 516, 2015. 
Earth Syst. Dynam. Discuss., doi:10.5194/esd-2016-57, 2016

Liu, Y., Ren, L., Zhu, Y., Yang, X., Yuan, X., Jiang, S., Ma, M. Evolution of Hydrological Drought in Human Disturbed Areas: A Case Study in the Laohahe Catchment, Northern China. Advances in Meteorology, 2016: doi: 10.1155/2016/5102568, 2016.

Lloyd-Hughes, B. \& Saunders, M. A. A drought climatology for Europe. Int J Climatol, 22(13): 1571 - 1592, 2002.

López-Moreno, J. I., Vicente-Serrano, S. M., Beguería, S., García-Ruiz, J. M., Portela, M. M., Almeida A. B. Dam effects on droughts magnitude and duration in a transboundary basin: The Lower River Tagus, Spain and Portugal. Water Resour Res, 45, W02405, doi: 10.1029/2008WR007198, 2009.

Low, K. G., Grant, S. B., Hamilton, A. J., Gan, K., Saphores, J. D., Arora, M. Feldman, D. L. Fighting drought with innovation: Melbourne's response to the Millennium Drought in Southeast Australia. WIREs Water, 2(4): 315 328, 2015.

Magrin, G.O., J.A. Marengo, J.-P. Boulanger, M.S. Buckeridge, E. Castellanos, G. Poveda, F.R. Scarano, Vicuña. S. Central and South America. In Barros et al. (eds.), Climate Change 2014: Impacts, Adaptation, and Vulnerability. Part B: Regional Aspects. Contribution of Working Group II to the Fifth Assessment Report of the Intergovernmental Panel on Climate Change. Cambridge University Press, Cambridge, United Kingdom and New York, NY, USA, pp. 1499-1566, 2014

McKee, T. B., Doesken, N. J. \& Kleist, J. The Relationship of Drought Frequency and Duration to Time Scales. Proceedings of the Eighth Conference on Applied Climatology, American Meteorological Society, Boston, 179 184,1993

Mehran, A., Mazdiyasni, O. \& AghaKouchak, A. A hybrid framework for assessing socioeconomic drought: Linking climate variability, local resilience, and demand. J Geophys Res, 120(15): 7520 - 7533, 2015.

Meza, F. J. Recent trends and ENSO influence on droughts in Northern Chile: An application of the Standardized Precipitation Evapotranspiration Index. Weather and Climate Extremes, 1: 51 - 58, 2013.

Montecinos, A., Díaz, A. \& Aceituno, P. Seasonal Diagnostic and Predictability of Rainfall in Subtropical South America Based on Tropical Pacific SST. J Climate, 13: 746 - 758, 2000.

Mounir, Z.M., Ma, C.M., Amadou, I. Application of Water Evaluation and Planning (WEAP): A Model to Assess Future Water Demands in the Niger River (in Niger Republic). Modern Applied Science, 5(1): 38 - 49, 2011.

Mutiga, J.K., Mavengano, S.T., Zhongbo, S., Woldai, T., Becht, R. Water Allocation as a Planning tool to Minimuse Water Use Conflicts in the Upper Ewaso Ng'iro North Basin, Kenya. Int Ser Prog Wat Res, 24(14): 3939 - 3959, 2010.

Nash, J. E. \& Sutcliffe, J. V. River flow forecasting through conceptual models, Part I - A discussion of principles. J Hydrol, 10: 282-290, 1970.

Nicholson, L., Marí, J., Lopez, D., Rabatel, A., Bown, F., Rivera, A. Glacier inventory of the upper Huasco valley, Norte Chico, Chile: glacier characteristics, glacier change and comparison with central Chile. Ann Glaciol, 50(53): 111- 118, 2009.

Rangecroft, S., Harrison, S., Anderson, K., Magrath, J., Castel, A. P., Pacheco, P. Climate Change and Water Resources in Arid Mountains: An Example from the Bolivian Andes. AMBIO, 42(7): 852 - 863, 2013. 
Earth Syst. Dynam. Discuss., doi:10.5194/esd-2016-57, 2016

Robertson, A.W., Baethgen, W., Block, P., Lall, U., Sankarasubramanian, A., de Assis de Souza Filho, F., Verbist, K. Climate Risk Management for Water in Semi-Arid Regions. Earth Perspectives, 1:12, 2014.

Petts, G.E. \& Gurnell, A.M. Dams and geomorphology: research progress and future directions. Geomorphology, 71: $22-47,2005$.

Prudhomme C., Giuntoli. I., Robinson E.L., Clark D.B., Arnell A.W., Dankers R., Fekete B., Franssen W., Gerten D., Gosling S.N., Hagemann S., Hannah D.M., Kim H., Masaki Y., Satoh Y., Stacke T., Wada Y., Wisser D. Hydrological droughts in the $21^{\text {st }}$ century: hotspots and uncertainties from a global multi-model ensemble experiment, Proceedings of the National Academy of Sciences (PNAS), 111 (9): 3262-3267, 2014.

Purkey, D.R., Joyce, B., Vicuna, S., Hanemann, M.W., Dale, L.L., Yates, D., Dracup, J.A. Robust analysis for future climate change impacts on water for agriculture and other sectors: a case study in the Sacramento Valley. Climatic Change, 87(1): 109 - 122, 2008.

Shukla, S. \& Wood, A. W. Use of a standardized runoff index for characterizing hydrologic drought. Geophys Res Lett, 35(2), 2008.

Spinoni, J., Naumann, G., Carrao, H., Barbosa, P., Vogt, J. World drought frequency, duration and severity for 1951 - 2010. Int J Climatol, 34: 2792 - 2804, 2014.

Stagge, J. H., Tallaksen, L. M., Gudmundsson, L., Van Loon, A. F., Stahl, K. Candidate Distributions for Climatological Drought Indices (SPI and SPEI). J Climatol, 35 (13): 4027 - 4040, 2015.

Svensson, C., Brookshaw, A., Scaife, A., Bell, V., Mackay, J., Jackson, C., Hannaford, J., Davies, H., Arribas, A., Stanley, S. Long-range forecasts of UK winter hydrology. Environ Res Lett, 10, 2015.

Tallaksen, L. M. Streamflow drought frequency analysis, in Drought and Drought Mitigation. In Vogt, J. V. \& Somma, F. (eds), Advances in Natural and Technological Hazards Research, Kluwer Academic Publishers, Dordrecht, the Netherlands, 14: 103-117, 2000

Tallaksen, L. M. \& Van Lanen, H. A. J. Hydrological Drought: Processes and estimation methods for streamflow and groundwater. Elsevier Science, 2004.

Tallaksen, L. M., Madsen, H. \& Clausen, B. On the definition and modelling of streamflow drought duration and deficit volume. Hydrological Sciences Journal, 42: 15 - 33, 1997.

Van Huijgevoort, M. H., Hazenberg, P., van Lanen, H. A. J. \& Uijlenhoet, R. A generic method for hydrological drought identification across different climate regions. Hydrol Earth Syst Sc, 16: 2437 - 2451, 2012.

Van Loon, A. F. Hydrological drought explained. WIREs Water, 2(4): 359 - 392, 2015.

Van Loon, A. F. \& Van Lanen, H. A. J. Making the distinction between water scarcity and drought using an observation-modeling framework. Water Resour Res, 49: 1483 - 1502, 2013.

Van Loon, A. F. \& Van Lanen, H. A. J. Testing the observation-modelling framework to distinguish between hydrological drought and water scarcity in case studies around Europe. European Water, 49: 65 - 75, 2015.

Van Loon, A. F., Gleeson, T., Clark, J., Van Dijk, A. I. J. M., Stahl, K., Hannaford, J., Di Baldassarrre, G., Teuling, A. J., Tallaksen, L. M., Uijlenhoet, R., Hannah, D. M., Sheffield, J., Svoboda, M., Verbeiren, B., Wagener, T., Rangecroft, S., Wanders, N., Van Lanen, H. A. J. Drought in the Anthropocene. Nat Geosci, 9: 89 - 91, 2016a.

Van Loon, A. F., Stahl, K., Di Baldassarre, G., Clark, J., Rangecroft, S., Gleeson, T., Van Dijk, A. I. J. M., Tallaksen, L. M., Hannaford, J., Teuling, A. J., Uijlenhoet, R., Hannah, D. M., Wanders, N., Sheffield, J., Svoboda, M., Verbeiren, B., Wagener, T., Van Lanen, H. A. J. Drought in a human-modified world: reframing drought definitions, understanding and analysis approaches. Hydrol Earth Syst Sc, 20: 3631 - 3650, 2016 b. 
Earth Syst. Dynam. Discuss., doi:10.5194/esd-2016-57, 2016

Manuscript under review for journal Earth Syst. Dynam.

Published: 16 November 2016

(c) Author(s) 2016. CC-BY 3.0 License.

Verbist, K., Robertson, A., Cornelis, W.M., Gabriels, D. Seasonal predictability of daily rainfall characteristics in central-northern Chile for dry-land management. J Appl Meteorol Clim, 49(9): 1938-1955, 2010.

Vicente-Serrano, S. M., González-Hidalgo, C. J., de Luis, M., Raventós, J. Drought patterns in the Mediterranean area: the Valencia region (eastern Spain). Clim Res, 26: 5 - 15, 2004.

Vicente-Serrano, S. M., López-Moreno, J. I., Beguería, S., Lorenzo-Lacruz, J., Azorin-Molina, C., Morán-Tejeda, E. Accurate computation of a Streamflow Drought Index. Journal of Hydrology Engineering, 17(2): 318 - 332, 2012.

Vicente-Serrano, S. M., Lopez-Moreno, J., Beguería, S., Lorenzo-Lacruz, J., Sanchez-Lorenzo, A., Gracía-Ruiz, J. M., Azorin-Molina, C., Morán-Tejeda, E., Revuelto, J., Trigo, R. Evidence of increasing drought severity caused by temperature rise in southern Europe. Environ Res Lett, 9(4), 2014.

Viviroli, D., Dürr, H., Messerli, B., Meybeck, M., Weingartner, R. Mountains of the world, water towers for humanity: Typology, mapping and global significance. Water Resour Res, 43(7), 2007.

Vogel, C. H. \& Drummond, J. H. Dimensions of drought: South African case studies. GeoJournal, 30(1): 93 - 98, 1993.

Wada, Y., Van Beek, L. P., Wanders, N., Bierkens, M. F. Human water consumption intensifies hydrological drought worldwide. Environ Res Lett, 8(3): doi: 10.1088/1748-9326/8/3/034036, 2013.

Wanders, N. \& Wada, Y. Human and climate impacts on the $21^{\text {st }}$ century hydrological drought. J Hydrol, 526: $208-220,2015$.

Wagnitz, P., Núñez, J. \& Ribbe, L. Cost of environmental flow during water scarcity in the arid Huasco River basin, northern Chile. Hydrological Sciences Journal, 59: 700 - 712, 2014.

Wang, G., Xia, J \& Chen, J. Quantification of effects of climate variations and human activities on runoff by a monthly water balance model: A case study of the Chaobai River basin in northern China. Water Resour Res, 45(7): doi: 10.1029/2007WR006768, 2009.

WMO, 2012. Standardized Precipitation Index User Guide. World Meteorological Organization, No. 1090 http://www.wamis.org/agm/pubs/SPI/WMO_1090_EN.pdf

WRI Aqueduct, 2014: Water Risk Atlas, http://www.wri.org/applications/maps/aqueduct-atlas

Wu, H., Soh, L. K., Samal, A., Hong, T., Marx, D., Chen, X. Upstream-Downstream Relationships in Terms of Annual Streamflow Discharges and Drought Events in Nebraska. Journal of Water Resource and Protection, 1 : $299-315,2009$.

Yevjevich, V. An objective approach to definitions and investigations of continental hydrologic droughts, Colorado state University Fort Collins, Colorado, 1967.

Zelenhasić, E. \& Salvai, A. A method of streamflow drought analysis. Water Resour Res, 23: 156 - 168, 1987. 
Earth Syst. Dynam. Discuss., doi:10.5194/esd-2016-57, 2016

Manuscript under review for journal Earth Syst. Dynam.

Published: 16 November 2016

(c) Author(s) 2016. CC-BY 3.0 License.

Earth System

Dynamics

Discussions

(c) (i)

Table 1: Data stations used for analysis, 1965 - 2013 (source: DGA, Chile)

\begin{tabular}{|l|l|l|l|l|l|}
\hline $\begin{array}{l}\text { Variable } \\
\text { measured }\end{array}$ & $\begin{array}{l}\text { Location } \\
\text { (catchment } \\
\text { area) }\end{array}$ & $\begin{array}{l}\text { Station name } \\
\text { (number) }\end{array}$ & Coordinates & $\begin{array}{l}\text { Elevation } \\
(\mathrm{m})\end{array}$ & $\begin{array}{l}\text { Annual mean } \\
(+/ \text { - range) }\end{array}$ \\
\hline Precipitation & Upstream & $\begin{array}{l}\text { Junta del } \\
\text { Carmen } \\
\text { (P3804007) }\end{array}$ & $\begin{array}{l}28.75731 \mathrm{~S} \\
70.48385 \mathrm{~W}\end{array}$ & 770 & $\begin{array}{l}49 \mathrm{~mm} \\
(0-234.5)\end{array}$ \\
\hline Discharge & $\begin{array}{l}\text { Upstream } \\
\left(1026.7 \mathrm{~km}^{2}\right)\end{array}$ & $\begin{array}{l}\text { Rio transito } \\
\text { antes junta rio } \\
\text { Carmen } \\
\text { (Q3806001) }\end{array}$ & $\begin{array}{l}28.75369 \mathrm{~S} \\
70.48495 \mathrm{~W}\end{array}$ & 812 & $\begin{array}{l}0.077 \mathrm{~mm} / \mathrm{d} \\
(0.0099-0.286)\end{array}$ \\
\hline Discharge & $\begin{array}{l}\text { Downstream } \\
\left.\text { (1516.4 } \mathrm{km}^{2}\right)\end{array}$ & $\begin{array}{l}\text { Rio Huasco en } \\
\text { Santa Juana } \\
\text { (Q3820003) }\end{array}$ & $\begin{array}{l}28.67536 \mathrm{~S} \\
70.64857 \mathrm{~W}\end{array}$ & 553 & $\begin{array}{l}0.074 \mathrm{~mm} / \mathrm{d} \\
(0.0061-0.309)\end{array}$ \\
\hline
\end{tabular}


Earth Syst. Dynam. Discuss., doi:10.5194/esd-2016-57, 2016

Manuscript under review for journal Earth Syst. Dynam.

Published: 16 November 2016

(c) Author(s) 2016. CC-BY 3.0 License.
Earth System

Dynamics

Discussions

\section{(c) (1)}

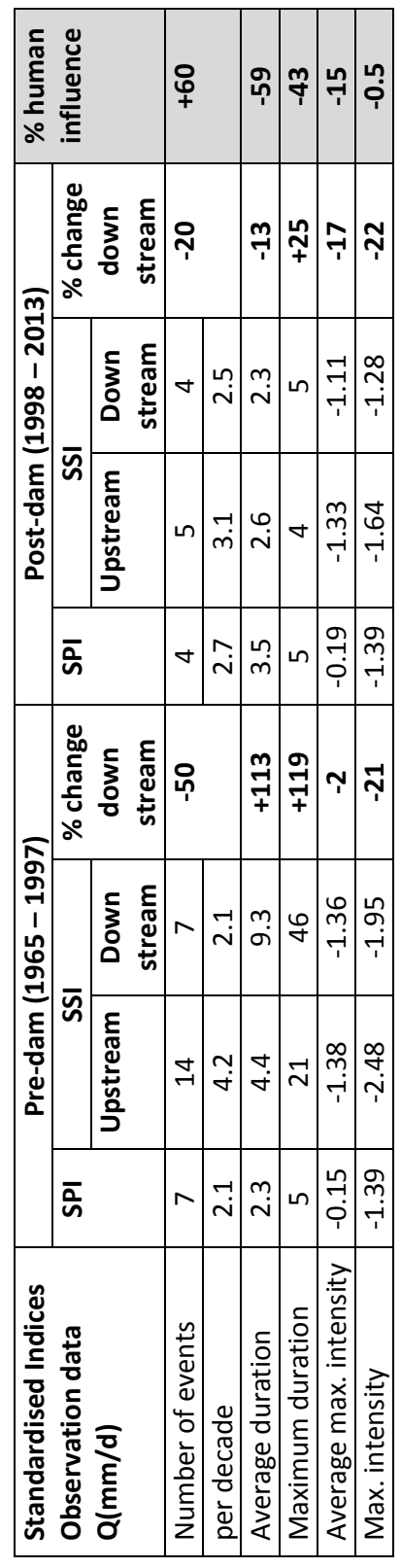


Earth Syst. Dynam. Discuss., doi:10.5194/esd-2016-57, 2016

Manuscript under review for journal Earth Syst. Dynam.

Published: 16 November 2016

(c) Author(s) 2016. CC-BY 3.0 License.
Earth System

Dynamics

Discussions

\section{(c) (1)}
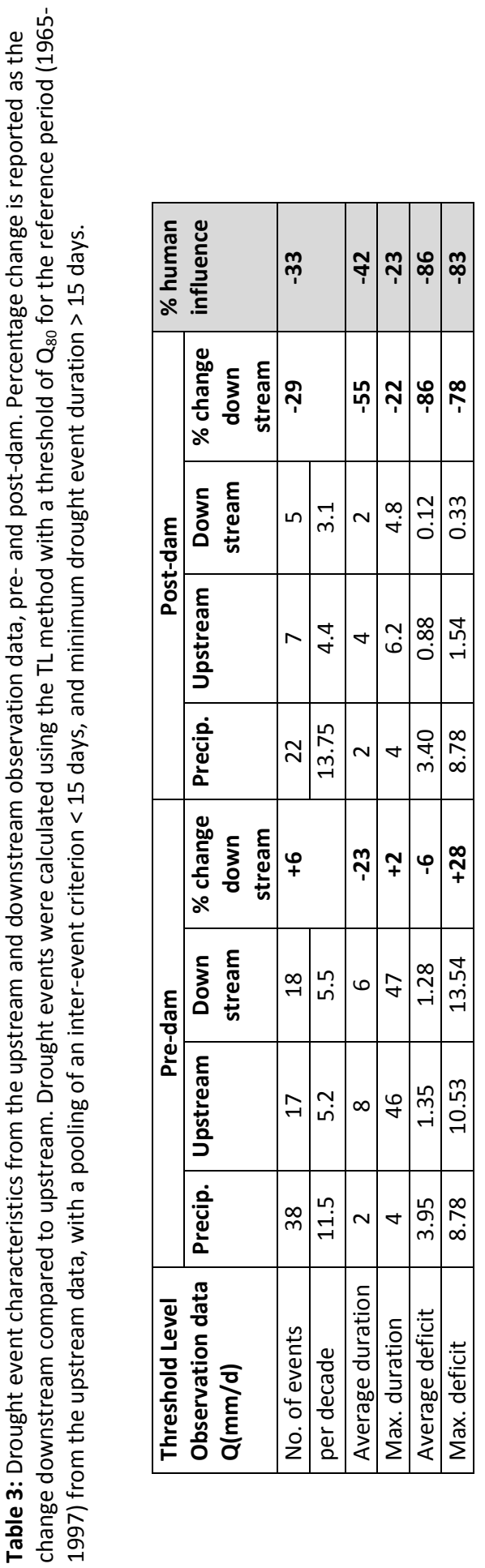
Earth Syst. Dynam. Discuss., doi:10.5194/esd-2016-57, 2016

Manuscript under review for journal Earth Syst. Dynam.

Published: 16 November 2016

(c) Author(s) 2016. CC-BY 3.0 License.

Table 4: Drought event characteristics calculated from WEAP modelled monthly data, the natural and human-influenced scenarios (1960 -2010). Percentage change is reported as the change human compared to natural. SI methods used the threshold of -1 to determine a drought event. TL method used a threshold of $Q_{80}$ from the natural scenario as the reference period. Intensity is only reported for SI method and deficit for the TL method.

\begin{tabular}{|c|c|c|c|c|c|c|}
\hline \multirow{2}{*}{$\begin{array}{l}\text { Modelled data } \\
\mathrm{mm} / \text { month } \\
(1960-2010)\end{array}$} & \multicolumn{3}{|c|}{ Standardised Indices } & \multicolumn{3}{|c|}{ Threshold Level } \\
\hline & Natural & Human & $\begin{array}{l}\text { \% human } \\
\text { influence }\end{array}$ & Natural & Human & $\begin{array}{c}\% \\
\text { human } \\
\text { influence }\end{array}$ \\
\hline Number of events & 15 & 12 & \multirow[t]{2}{*}{-20} & 14 & 28 & \multirow[t]{2}{*}{+100} \\
\hline No. of events per decade & 3.1 & 2.5 & & 2.9 & 5.8 & \\
\hline Average duration & 4.1 & 3.6 & -12 & 7.9 & 4 & -47 \\
\hline Maximum duration & 11 & 11 & 0 & 45 & 35 & -22 \\
\hline Average max. intensity/deficit & -1.4 & -1.4 & +2 & 1.19 & 0.55 & -54 \\
\hline Maximum intensity/deficit & -2.1 & -1.8 & -14 & 8.14 & 6.88 & -15 \\
\hline
\end{tabular}


Earth Syst. Dynam. Discuss., doi:10.5194/esd-2016-57, 2016

Manuscript under review for journal Earth Syst. Dynam.

Published: 16 November 2016

(c) Author(s) 2016. CC-BY 3.0 License.

Table 5: Changes observed between upstream and downstream stations for $Q_{\mathrm{obs}}$ and between natural and human scenarios for $\mathrm{Q}_{\text {sim }}$ the different methods (SI \& $\mathrm{TL}$ ). A blue symbol represents a decrease in drought characteristics due to the human influence (alleviation); a red symbol represents an increase in drought characteristics due to the human influence (aggravation). A coloured outline represents a minor change $(< \pm 50 \%)$ due to human influence, and a block colour symbol represents a major change $(> \pm 50 \%)$. $\equiv$ represents the same as, $\approx$ means nearly equal to (zero $\pm 5 \%$ ).

\begin{tabular}{|c|c|c|c|c|c|c|c|c|}
\hline \multirow{3}{*}{$\begin{array}{l}\text { Compared methods } \\
\% \text { change downstream }\end{array}$} & \multicolumn{4}{|c|}{ Qobs } & \multicolumn{4}{|c|}{$\mathbf{Q}_{\text {sim }}$} \\
\hline & \multicolumn{2}{|c|}{ Pre-dam } & \multicolumn{2}{|c|}{ Post-dam } & \multicolumn{2}{|c|}{ Pre-dam } & \multicolumn{2}{|c|}{ Post-dam } \\
\hline & SI & TL & SI & TL & SI & TL & SI & TL \\
\hline No. of events & & $\Lambda$ & $\nabla$ & & $\nabla$ & & & \\
\hline Average duration & & $V$ & & & $\approx$ & & $\equiv$ & \\
\hline Max. duration & & $\approx$ & & & $\equiv$ & & & \\
\hline Average max. intensity/deficit & $\approx$ & $\nabla$ & & & $\approx$ & & $\Delta$ & \\
\hline Max. intensity/deficit & & $\Delta$ & & & & & $\angle$ & \\
\hline
\end{tabular}


Earth Syst. Dynam. Discuss., doi:10.5194/esd-2016-57, 2016

Manuscript under review for journal Earth Syst. Dynam.

Published: 16 November 2016

(c) Author(s) 2016. CC-BY 3.0 License.

Table 6: Changes during the post-dam period between the natural and human-influenced situation for the different data, $Q_{\text {obs }}$ and $Q_{\text {sim }}$ and methods, $S I$ and TL. A blue symbol represents a decrease in drought characteristics due to the human influence (alleviation); a red symbol represents an increase in drought characteristics due to the human influence (aggravation). A coloured outline represents a minor change $(< \pm 50 \%)$ due to human influence, and a block colour symbol represents a major change $(> \pm 50 \%)$. $\equiv$ represents the same as, $\approx$ means nearly equal to (zero $\pm 5 \%$ ).

\begin{tabular}{|l|c|c|c|c|}
\hline \multirow{2}{*}{$\begin{array}{l}\text { \% human influence } \\
\text { post-dam }\end{array}$} & \multicolumn{2}{|c|}{ SI } & \multicolumn{2}{c|}{ TL } \\
\cline { 2 - 6 } & $\mathbf{Q}_{\text {obs }}$ & $\mathbf{Q}_{\text {sim }}$ & $\mathbf{Q}_{\text {obs }}$ & $\mathbf{Q}_{\text {sim }}$ \\
\hline No. of events & & & $\nabla$ & \\
\hline Average duration & $\checkmark$ & $\equiv$ & $\nabla$ & $\nabla$ \\
\hline Max. duration & $\nabla$ & & $\nabla$ & $\nabla$ \\
\hline Average severity & $\nabla$ & $\triangle$ & & $\nabla$ \\
\hline Max. severity & $\approx$ & $\triangle$ & & $\nabla$ \\
\hline
\end{tabular}


Earth Syst. Dynam. Discuss., doi:10.5194/esd-2016-57, 2016

Manuscript under review for journal Earth Syst. Dynam.

Published: 16 November 2016

(c) Author(s) 2016. CC-BY 3.0 License.

Table 7: Sensitivity analysis: Percentage change downstream of $\mathrm{Q}_{\mathrm{obs}}$ data using SI and TL methods (left) with sensitivity analysis results (right). Blue represents a decrease in characteristics, red an increase, with a block colour symbol representing a change greater than $\pm 50 \%$.

\begin{tabular}{|c|c|c|c|c|c|c|c|c|}
\hline \multirow{3}{*}{$\begin{array}{l}\text { Direction of change } \\
\text { downstream }\end{array}$} & \multicolumn{4}{|c|}{ Qobs } & \multicolumn{4}{|c|}{ Qobs $_{\text {sensitivity analysis }}$} \\
\hline & \multicolumn{2}{|c|}{ Pre-dam } & \multicolumn{2}{|c|}{ Post-dam } & \multicolumn{2}{|c|}{ Pre-dam } & \multicolumn{2}{|c|}{ Post-dam } \\
\hline & SI & TL & SI & TL & SI & TL & SI & TL \\
\hline No. of events & & $\Lambda$ & & & & $\Lambda$ & & \\
\hline Average duration & & & & & & $\Lambda$ & & \\
\hline Max. duration & & $\approx$ & & & & $\approx$ & & \\
\hline Average max. intensity/deficit & $\approx$ & & & & & $\Lambda$ & & \\
\hline Max. intensity/deficit & & 7 & & & & 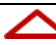 & & \\
\hline
\end{tabular}


Earth Syst. Dynam. Discuss., doi:10.5194/esd-2016-57, 2016

Manuscript under review for journal Earth Syst. Dynam.

Published: 16 November 2016

(c) Author(s) 2016. CC-BY 3.0 License.

Table 8: Sensitivity analysis for the percentage of human influence (calculated from observed compared to expected). Blue represents a decrease in characteristics, red an increase, with a block colour symbol representing a change greater than $\pm 50 \%$.

\begin{tabular}{|l|c|c|c|c|}
\hline \multirow{2}{*}{$\begin{array}{l}\text { \% human } \\
\text { influence }\end{array}$} & \multicolumn{2}{|c|}{ Qobs } & \multicolumn{2}{c|}{$\begin{array}{c}\text { Sensitivity } \\
\text { analysis }\end{array}$} \\
\cline { 2 - 5 } & SI & TL & SI & TL \\
\hline No. of events & & $\checkmark$ & $\checkmark$ & $\checkmark$ \\
\hline Average duration & & $\checkmark$ & & $\sim$ \\
\hline Maximum duration & $\nabla$ & $\nabla$ & & \\
\hline Average severity & $\nabla$ & & $\approx$ & $\nabla$ \\
\hline Maximum severity & $\approx$ & & $\approx$ & $\approx$ \\
\hline
\end{tabular}

